\title{
Accommodation of Ethnic Diversities and Nurturing Unity in Ethiopia: Appraising Benishangul Gumuz Regional State Practice
}

\author{
Muluneh Kassa Eresso (PhD) \\ Assistant Professor in Federalism and Governance Studies under Federal Democratic Republic of Ethiopia
}

\begin{abstract}
Federalism as a political idea has become increasingly important as a way of peacefully reconciling the principles of unity and diversity typically in multi-national states. Actually, federalism is not a universal remedy for all challenges of ethnic diversity or ethnic conflicts rather it has considered as a means to achieve the end particularly in ethnically heterogeneous states. Therefore, the very objective of this paper is to critically examine the actual practices of unity in diversity at Benishangul-Gumuz regional state (hereafter used as BGRS). In this context, this paper investigate in detail policies and institutions designed for accommodation of ethnic diversity in the study region. Based on the information gained through the various research instruments the writer concluded that non-indigenous ethnic groups are in a better manner accommodated at Kebele level of government than Woreda and regional levels of government in BGRS. Therefore, failure to adequately accommodate non-indigenous ethnic groups particularly in the regional legislative and executive organs and Woreda executive organ of the government in its part challenging the unity of BGRS.
\end{abstract}

Keywords: Federalism; Accommodation of Diversity; Ethnic Diversity; Ethnic Unity; BGRS; Indigenous and Non-indigenous Ethnic Group

DOI: $10.7176 /$ RHSS/10-1-01

Publication date: January $31^{\text {st }} 2020$

\section{Introduction}

Diversity as a social fact always exists everywhere in the world. But in most countries ethno-linguistic diversities have been considered as a burden to realize state unity. As a result states have attempted to adopt a nation-state project, which is one culture, one language and one nation to achieve national unity at the expense of their existing diversities. Similarly, in the previous regimes of Ethiopia, ethnic diversity was considered as a burden hence a nation state project was dominantly accepted project to achieve national unity. In fact, there are two main reasons why diversity within the state territory becomes a problem. First, when the social, cultural, or racial differences become the basis of group inequality. Second, when the different groups perceive one another as inferiors or superiors (Majeed et al. in Watts and Chattopadhyay, 2008, ed).

It is fact that, diversity is one of the most contested issues in domestic and international politics (Moreno and Colino, 2010: 3). Hence, in current political dynamics managing diversity has emerged as the foremost overarching and urgent issue basically in multi-ethnic states. Questions concerning how diversities should be recognized and accommodated in ethno-linguistically and culturally heterogeneous states are among the most important political agenda for democratic and democratizing societies today (Gutmann, 1994; Assefa, 2007). Currently, accommodation of diversity has been salient issues either in developed or developing states.

The overarching aim why ethnic federalism has been opted in Ethiopia since 1991 was primarily to respond to the past ethno-cultural injustice. Means federalism as the institutional arrangement has selected primarily to realize the challenges of ethnic diversity. For example, according to FDRE constitution every nation, nationality and people in Ethiopia has the right to a full measure of self-government which includes the right to establish institutions of government in the territory that it inhabits and to equitable representation in state and federal governments (Art 39(3)). In a similar vein, BGRS constitution also clearly recognized that the government shall promote and support the people's self-rule at all levels of government and also respect the identity of nationalities and peoples of the region (refer Art 110 ( 1 and 2) of BGRS constitution). Accordingly, the government shall have the duty to strengthen ties of equality, unity and fraternity among the nationalities and peoples of the region (ibid).

The institutional accommodation and fair representation of ethnic cleavages of the regional state can be used as the best indicator for the inclusive political participation of the existing diversity in the region. The institutional response that suggests a state to move away from the nation-state paradigm towards a politics of recognition and accommodation, is presented as a promising alternative in diversified states (Yonatan, 2008). A corollary of the decision to adopt the principle of recognition is the espousal of institutional measures that supplement the act of recognition and provide the practical effect thereto (ibid).

There are various mechanisms that can be used to manage ethnic diversity in multi-ethnic states. But under this paper constitutional and institutional mechanisms of accommodation of ethnic diversity will be selected and analyzed. Hence, the writer assesses the institutional structure and how BGRS recognizes and accommodates its multi-ethnic nature and how this is translated into different regional and local institutional realities. And also the 
paper tries to assess how the institutional principles of self-rule and shared-rule matrix can and have been translated into institutional arrangements practically in the region to realise the capacity of federalism to the challenges of ethnic diversity in the region.

To this end, this study has addressed the following key research questions: How could the imperatives of regional unity and diversity be reconciled in the Benishangul Gumuz Regional State? Has Benishangul Gumuz Regional State Constitution provided a legal and institutional framework for accommodating the diverse groups in the region? And what does the trend look like so far?

\subsection{Objectives of the Study}

The objectives of this study are:

1) To examine whether the imperatives of regional unity and diversity are reconciled or not practically under Benishangul Gumuz regional state.

2) To investigate in detail policies and institutions designed for accommodation of ethnic diversity in Benishangul Gumuz regional state.

\subsection{Methodological Approach}

In order to achieve the intended purpose, it is mandatory to clearly explain the appropriate methodology used in this scientific study. The strategy preferred to perform this inquiry was a mixed method design specifically concurrent embedded design. Under this inquiry both qualitative and quantitative data were collected simultaneously. In fact, in this study priority was given to qualitative data. They were supported through analysis of quantitative data. Therefore, in order to obtain qualitative data, in depth-individual interview, personal observation, different legal and other document analysis were conducted. Here, qualitative approach was selected as a primary method because of its holistic and flexible nature; hence, the participants had the opportunity to respond more elaborately and in-greater detail. While, in this study quantitative data were collected through a survey questionnaire.

The research targeted all different ethnic groups residing in the region permanently for a long period and new migrants. It was very difficult to collect data from each of the 20 Woredas of the region. Therefore, 5 Woredas were selected purposely because of the nature and magnitude of ethnic diversity in the region. More specifically, at the Asossa Zone (Bambasi and Assosa Woredas) were selected as sample study. At the Metekel Zone (Dangur, Debati and Wombera Woreda) were selected as sample study.

More specifically, the target respondents in this study were higher officials at the regional level and the advisors of regional president, the regional state council advisors, residents of different ethnic groups in the region, members of regional and local levels of government executive and legislative councils, and ruling and opposition party leaders and members. Thus, the respondent selection technique was mainly based on purposive and convenience sampling techniques. These were selected because knowledgeable persons with the desired expertise were to be appropriate for the purpose at hand.

The researcher used a table produced by (Krejcie and Morgan, 1970 quoted in Cohen et al., 2000: 94) to determine the sample size for a survey questionnaire under this study. Accordingly, out of the total public servants of 25982 (in the year of 2016), a sample of 379 respondents was randomly taken for a survey questionnaire. In this context, before beginning to distribute the questionnaire, two general categories of people to whom the questionnaire should be distributed were categorized. The target groups included indigenous ethnic groups from the regional government civil servants to the lower levels of government unit, and from nonindigenous ethnic groups who are regional government civil servants similarly from the regional to the lower levels of the government unit. Therefore, $52.2 \%$ survey respondents were from indigenous ethnic groups while $47.8 \%$ were from non-indigenous ethnic groups.

\subsection{Meaning of Indigenousness in BGRS Context}

In fact, as for many other terminologies, there is no universally accepted identification criterion to determine certain society as indigenous and others as non-indigenous under every state (Muluneh, 2017). "The term indigenous punctuates the political landscape in developed and developing countries, in the East and in the West (ibid). Its politics revolve around four different types of claims: participation and representation; access to resources; autonomy and self-government; and the protection of language and culture" (Jung, 2008: 184).

BGRS connotes early inhabitants and to emphasize their status as a people living in the place prior to subsequent settlement and who identified themselves, as part of politically, economically and socially marginalized groups during the former regimes (Muluneh, 2017). The interviewees also described that the major reason why the term indigenous has been incorporated vividly in the regional constitution is likely to promote the rights to autonomy or self-government in the matter relating to their internal and local affairs and freely pursue their own traditional institutions, economic, political, social and cultural development in the region (ibid). The indigenous ethnic groups' historic marginalization and isolation from the center may be addressed by the 
regional action and hence explicit constitutional recognition of indigenous ethnic groups signifies the practical steps of the region to protect ethnic rights (ibid).

The minutes of the Constitutional Assembly held in Assosa 03/12/2002 also reveal a somewhat similar viewpoint as that of the interviewees. As per this minute, the term indigenous peoples in BGRS is described as:

People inhabiting the region in primacy was considered as indigenous to the region, but one thing everyone should remember here is that other Ethiopian people's rather than indigenous ethnic groups were not considered as an oddity and migrant they are Ethiopian (for further information refer appendix-6, Minutes of the Constitutional Assembly held in 03/12/2002, Assosa, Volume 1, here the Amharic version was translated by the researcher).

The main assumption and description concerning the meaning of indigenous peoples by the minute of the conference is quite clear (Muluneh, 2017). As per the minute of the conference, the major criterion to describe and determine peoples of the region as indigenous and other peoples are their early settlement in the area (i.e. Benishangul Gumuz Region). In addition to this, their historic claim to a historic and particularly strong bond with certain territories they have occupied before the establishment of the federal state structure in the country and seek to enhance the maintenance of their cultural identities of indigenous peoples including land rights and political/territorial autonomies is also a significant part of dichotomization (ibid).

Therefore, based on the above information, the researcher claimed that the term indigenous is a politically constructed ethnic identity by the concerted effort of the then political actors as a strategy to promote access to political power in the region.

\subsection{Mechanisms of Management of Diversity}

Basically, in African states, diversities are considered as a burden. However, diversity as a social fact always existed in the world-at-large, but it becomes a "problem" mainly when it exists within the territory of a state (Majeed et al in Watts and Chattopadhyay, 2008, ed.). Hence, in the current political dynamics, managing diversity has emerged as the foremost overarching and urgent issue in ethnically heterogeneous states. There are different methods that can be used to manage ethnic diversity in ethnically heterogeneous states. For instance, containment approach, assimilationist strategy, power sharing, providing autonomy, representation, and recognition. In fact, both containment and assimilationist approaches are pernicious strategies.

In Ethiopia, federalism as the institutional arrangement has been opted primarily to address the challenges of ethnic diversity. The regional states are also responsible to recognize and promote the existing diversity based on their own local context. When seeking better constitutional accommodation within a multinational state, the aspirations of sub-state national societies touch upon both legal and political elements (Stephen, 2004). One example of the former is the amendment (or the re-interpretation) of the formal constitution, whereas the political elements can be identified in the refinement of constitutional conventions, practices and principles, or the political culture and value system informing the given constitution (ibid). There are three major areas to which sub-state national societies aspire regarding constitutional accommodation. Such as providing autonomy, representation, and recognition of their diverse features (ibid).

\subsubsection{Providing Autonomy}

As Stephen (2004) observes, it is in the context of autonomy that sub-state ethnic groups demand asymmetry or otherwise said self-governing rights. Autonomy in this context means that regional or sub-national societies might seek additional or distinctive powers in comparison to the rest of the country, and these powers shall be constitutionally entrenched. These powers usually allow regional societies to autonomously manage specific issues that are of particular interest to them and that are limited to domestic policy areas (from education to social policies, economic development and cultural aspects, etc.) (Nicola \& Lecours, 2008). In other words, these groups demand some form of political autonomy or territorial jurisdiction, so as to ensure the full and free development of their cultures and the best interest of their people (Kymlicka, 1995). Some scholars have talked in this regard of strengthening the minorities' voice at the periphery (Nicola \& Lecours, 2008) and this can be done through different tools, including devolution of powers or a federal system (in cases where a federal structure is not yet in place) (ibid). In both cases, this solution might entail a significant change in the structure of the state (ibid).

\subsubsection{Representation}

Here the representation refers to situations where the ethnic diversity inherent in the regional state is reflected within regional and local institutions; in other words, the presence of representatives of the different ethnic groups within regional and local institutions is enhanced. In this regard enhancing the voice of each ethnic group at the regional state, so that the regional state is no longer construed of as a single ethnic community, but is perceived as a compact of peoples. Hence, representation occurs in different ways. There can be the creation of regional bureaucratic position designed to the regional ethnic diversity. It can also occur with the creation of the regional chamber representing the interests of different cleavages of the region or through some form of representation within the constitutional interpretation council of the region. It might also take the shape of a 
share of parliamentary seats for ethnic groups (emphasis added).

\subsubsection{Recognition}

The struggle of sub-state ethnic groups for enhanced or better recognition is an issue that is intimately linked to the autonomy and representation (Stephen, 2004). Usually, with this notion, scholars refer to the aspiration of constitutional recognition of the language of the sub-state national society or of some other symbolic issues such as flags, anthems or other totems (ibid). In multinational states or federations, where the linguistic cleavage is a major component, official bi- or multi-lingualism is actually a preferred tool to give minorities a platform to express their voice at the centre, and this type of policy can also increase minority representation in such institutions such as parliament, the courts, the army and the bureaucracy, as it facilitates the advancement for linguistic minorities (Nicola \& Lecours, 2008). In other words, recognition is intimately related to the very essence of the alleged distinctiveness of the sub-state national group, its behaviors, traditions, and traits that allow clearly identifying and singling out one sub-state national group from the others. In very general terms, Taylor praises recognition as it partially shapes one's identity; consequently, [n]onrecognition or misrecognition can inflict harm, can be a form of oppression, imprisoning someone in a false, distorted, and reduced mode of being (Taylor, 1994:25). Due recognition becomes for Taylor a "vital human need" (ibid: 26).

\subsection{Overview of Administrative Arrangement of BGRS Government}

The constitution of BGRS has clearly stated that the regional government shall be organized with four hierarchically structured tiers of government. These are regional government, nationality administration, Woreda and Kebele administrations (Art 45(1) of BGRS constitution). All these tiers of government under the region have been empowered to have their own legislative, executive as well as judicial institutions under their respective jurisdictions. But in contrast the practice on the ground indicates that the regional state has preferred to establish the region with three de facto administrative Zones (Metekel, Assosa and Kemashi Zones) rather than nationality administration as per constitutional decree. Accordingly, under these three Zonal administrations there are 20 Woreda and 475 Kebele administrations. Actually, all tiers of government have their own institutions and agencies in which decisions and decision-making processes are carried out in BGRS. In this regard, except de facto Zone, constitutionally all administrative hierarchies beginning from the region down to the Kebele level have their own legislative, executive and judicial institutions.

\subsection{Regional Legislative Organ and Ethnic Composition}

According to FDRE constitution states have law making power over certain subject-matter provided to them. In this regard, for instance Art 52 of FDRE constitution stipulates that states shall have the power to enact and execute the state constitution and other laws, in addition to residual powers. Each state is allotted with the right to adopt its own constitution and thereby structure its own political institutions to embrace diverse ethnic groups' self-administration in a particular territory. Hence, in the Ethiopian federation, regions were created with legislative, executive and judicial functions in their respective jurisdiction.

The legislative authority of each state government is vested in the hands of the state council, which is also the highest organ in the region. It is also a unicameral chamber. The regional council is a body directly elected through the plurality electoral system. The members of this council are representatives of the people of the regional state as a whole, and they are elected for a term of five years through direct elections. Regional state council is the representative of the nation, nationalities of the regional state and its members are accountable to the people, and constitution and their conscience (see Proclamation No. $31 / 2002$, Article 48 (3) of BGRS. Thus, currently, the BGRS council consists of 99 councilors elected directly by the people through free, direct and fair elections by secret ballot for a term of five years in each electoral district by using the FPTP electoral system (see Art 48(1\&2) of BGRS constitution).

In accordance with the regional constitution, regional legislative council (regional parliament) is empowered to call chief executive bodies (i.e. the regional president and vice- presidents) and other regional officials for questioning and to investigate the executive's conduct and the discharge of its responsibilities (Art $49(3) / 17$ of BGRS constitution). Here, it is quite clear that in addition to the preparation of regional policies and laws, the regional legislative council has the power of oversight or follow-up the activities of executive council basically the implementation of laws and policies by the concerned body in the region.

Art 39(3) of FDRE constitution unequivocally recognized "every nation, nationality and people in Ethiopia has the right to a full measure of self-government which includes the right to establish institutions of government in the territory that it inhabits and to equitable representation in state and federal government." As a matter of fact, BGRS is ethnically diversified region hence, the regional institutional design should promote inclusiveness by reflecting the region's ethnic diversity and enhancing inclusive decision-making. Because, in multi-ethnic states an institutional design that echoes the existing diversities by using various mechanisms which protect the interest of diverse ethnic groups at different levels of government has been considered as one basic means to enhance peaceful coexistence among the ethnic segments. 
In fact, in this context, it is widely accepted by political analysts and policy-makers that federalism with genuine power-sharing is the most viable democratic means of managing conflict in countries with deep divisions, where ethno-nationalist groups are politically mobilized and identity is politically salient. Power sharing is necessary to prevent dominant groups or communities from subjugating others. In this regard, Lijphart explains that:

It is in the nature of consociational democracy, at least initially, to make plural societies more thoroughly plural. Its approach is not to abolish or weaken segmental cleavages but to recognize them explicitly and to turn the segments into constructive elements of stable democracy. $(1977, p .42)$

Therefore, the establishment and strengthening of the power-sharing mechanisms in different institutions from the local to the federal level in diversified state seems a precondition for cementing unity in diversity and cementing democracy at all levels. This principle can be broadened to state that regional institutions should reflect existing diversity on the ground. In this context, BGRS constitution generally accredited special representation of numerically minor indigenous ethnic groups and non-indigenous ethnic groups in the regional council. For instance, more specifically Art 48 (2) and 45 (3) of BGRS constitution respectively declare that the representation of Mao and Komo nationalities and other people of the region in the regional council shall be given special consideration where the details are to be decided by law but till now the law has not been enacted by the region.

In spite of this fact, data gathered by the researcher (2016) reveal that the current practice shows that out of the total 99 seats of the regional legislative council 40 are reserved for Bertha, 35 are reserved for Gumuz, 11 are reserved for Shinasha, 2 are reserved for Mao and 2 for Komo and the remaining 9 seats are reserved for nonindigenous ethnic groups by the 'quota' base. In fact, the base of this quota system is not the imperative of regional constitutional and other legal document, rather it has been the voluntary decision of the regionally based ruling political party to accommodate non-indigenous ethnic groups in BGRS. Here it is quite clear that, 90 seats were reserved for indigenous ethnic groups while only 9 seats were reserved for non-indigenous ethnic groups.

Thus, indigenous ethnic groups had a majority of representation and seats compared to non-indigenous ethnic groups in the regional council. In addition to this, currently non-indigenous ethnic groups were also represented in the regional legislative council standing committees. Consequently, out of the total 22 members of all standing committees in the regional legislative council 16 were nominated from indigenous ethnic groups while 6 members were nominated from the non-indigenous ethnic groups. At this point it is quite clear that, indigenous ethnic groups had a majority of representation and seats compared to non-indigenous ethnic groups in the regional council.

Therefore, based on the above empirical information one cannot argue that non-indigenous ethnic groups are fairly represented in the regional council in accordance with their high population number in the region. Actually, the representation of non-indigenous ethnic groups in regional council is not proportional. But in contrast, quite obviously, effective representation of various ethnic groups in various regional institutions has a profound effect to enhance the sense of regional unity in diversity. This means, among other things, in multiethnic constituent units the representation and inclusion of ethnic diversity is considered as glue to enhance sense of regional unity, consequently it has the potential to minimize or eliminate ethnic conflict/tension.

In addition to information gained through interviews, this study attempted to survey the existing perception of civil servants concerning the representation of ethnic diversities in the regional legislative council and its effect on regional unity of BGRS. Accordingly, the survey result shows that currently the restriction of the representation of non-indigenous people in the regional legislative council has been perceived as one major source of regional disunity. For instance, the results in the table 1.3 below show that a significant majority $(62.3 \%)$ of the respondents viewed that absence of proportional representation of non-indigenous ethnic groups under the regional legislative council in BGRS was a source of regional disunity, while few respondents $(28.5 \%)$ did not agree that this was a source of regional disunity in BGRS. 
Table 1.3. The Perception of Civil Servants Regarding the Effect of Absence of Proportional Representation of Ethnic Diversities in Regional Legislative Council vis-à-vis Regional Unity in BGRS.

\begin{tabular}{|c|c|c|c|c|c|}
\hline \multirow{7}{*}{ Valid } & Rank Scale & Frequency & Percent & Valid Percent & Cumulative Percent \\
\hline & Strongly agree & 128 & 33.8 & 34.9 & 34.9 \\
\hline & Agree & 108 & 28.5 & 29.4 & 64.3 \\
\hline & Undecided & 23 & 6.1 & 6.3 & 70.6 \\
\hline & Disagree & 92 & 24.3 & 25.1 & 95.6 \\
\hline & Strongly disagree & 16 & 4.2 & 4.4 & 100.0 \\
\hline & Total & 367 & 96.8 & 100.0 & \\
\hline Missing System & & 12 & 3.2 & & \\
\hline Total & & 379 & 100.0 & & \\
\hline
\end{tabular}

Source: Survey data, 2016-2017

Yet, the quota system designed and practiced to ensure non-indigenous ethnic group's participation in the regional legislative council has not adequately addressed their interest in BGRS. The main rationale behind the restriction of non-indigenous ethnic group representation in the regional political institutions was basically to break the non-indigenous ethnic group monopoly on regional government jobs and the regional economy. In fact, yet, in BGRS non-indigenous ethnic groups have significantly dominated the business sectors in the region (Interview conducted with expert in the regional trade, industry and transport bureau (2017), Assosa). Beside this, most of the civil service and judiciary institution's expertise positions were highly dominated by members of non-indigenous ethnic groups. The participation of indigenous ethnic groups in civil service, judicial positions and business sectors are still minimal in BGRS. In this regard, the regional government position was that it is one basic mechanism to counterbalance the socio-economic dominance of non-indigenous ethnic groups in BGRS. Indeed, in BGRS context, enabling the over representation of indigenous ethnic groups in the regional political institutions has profound implication to eliminate the effects of previous regime's socio-economic and political marginalization. Despite this fact, in BGRS non-indigenous ethnic groups felt the need for proportional representation in regional political institutions. For instance, in support of the above statements, interview conducted with higher regional officials uniformly substantiate that:

Notwithstanding, the fact that until now, non-indigenous ethnic groups have a political request for proportional representation in political institutions at different levels of government, the main reason why the regional government deliberately restricted the representation of non-indigenous in political institutions at different levels of government in the region was taken as 'a special mechanism' to counterbalance the socioeconomic domination of non-indigenous ethnic groups in the regional state. Nevertheless, yet both inadequate representation of non-indigenous ethnic groups in political institutions and the prevalence of socio-economic inequality between indigenous and non-indigenous ethnic groups have in its part significantly affected the enter-ethnic unity in the region (Interview conducted with officials(2016), Assosa).

Actually, in BGRS there exists a high socio-economic disparity between indigenous and non-indigenous ethnic groups in the region. For instance, illiteracy level is still quite high among indigenous ethnic groups compared with non-indigenous in the region. Indeed, the literacy rate is one basic indicator of socioeconomic development among the society. Yet, as stated above in BGRS non-indigenous ethnic groups have significantly dominated the business sectors in the region. Beside this, currently most of the civil service and judiciary positions are highly dominated by non-indigenous ethnic groups. The participation of indigenous ethnic groups in civil service, judicial positions and business sectors are still minimal in BGRS. Here, the prevalence of socioeconomic disparity among the ethnic groups has been considered as one major issue which challenges the promotion of inter-ethnic unity.

Beside this, another key issue hindering the effective representation of various ethnic groups in the legislative council at different levels of government in Ethiopia in general and BGRS in particular is the adopted electoral system. Though currently there are attempts of modifying it, Ethiopia has been using the "first-past-thepost" electoral system which simply states that one who receives the simple majority of votes within the electoral district will be the winner (see Proclamation No 532/2007, Art 25). The regional states are not allowed to formulate their own electoral system in contemporary Ethiopia. The power to enact laws concerning elections so as to give practical effect to the political rights is the duty of the federal government (see Art 51(15) of FDRE Constitution). Thus, adopting a uniform electoral system throughout the country without considering the particular situation of the regional states has bad effects on the representation of each ethnic group at different levels of government in the multi-ethnic areas. 
Hence, the "first-past-the-post" electoral system for electing the regional legislative council representatives in BGRS has the potential to exclude ethnic communities in the legislative council. In fact, special representation of ethnic minorities is recognized in BGRS constitution, but the actual scheme used to choose the representatives contradicts the intention of genuine ethnic representation. For instance, on this issue, some of the interview respondents alluded that the dominant regional political party/BGPDP, which belongs to indigenous ethnic groups has implicitly set perquisite criteria to choose the representatives of non-indigenous ethnic groups in accordance with BGPDP loyalty which is actually opposed to genuine representation of ethnic diversity.

As stated elsewhere in this paper, actual ethnic representation and participation in local political institutions will enable all ethnic groups to take charge of their own affairs and simultaneously it enhances harmony among the ethnic groups. In multi-ethnic areas as much as possible all ethnic groups should effectively be included in various political institutions at different levels of government, which has the potential to minimize or eliminate ethnic conflict/tension. However, the practice on the ground in BGRS shows that, the participation of nonindigenous ethnic groups in regional legislative council have been restricted. In this context, beside others one key issue hindering the effective representation of various ethnic groups in the legislative council at different levels of government in Ethiopia in general and BGRS in particular is the adopted electoral system.

The "first-past-the-post" electoral system for electing the regional, Woreda and Kebele legislative council representatives in BGRS has the potential to exclude ethnic communities in the legislative council. Therefore, biased legislative council formation, mainly as a result of the "first-past-the-post" electoral mode of choosing nominees in ethnically diversified state, may further exclude non-indigenous ethnic groups in the executive council by using the system of executive council formation policies possibly aimed at the exclusion of nonindigenous ethnic communities in BGRS.

\subsubsection{Regional Executive Organ and Ethnic Composition}

Art 57(1) of BGRS constitution stipulates that "the executive power of the region is vested in the chief executive and the executive council." The composition and competences of these organs are largely similar to those from other regions. The executive council is constituted of the chief executive, the deputy chief executive and members of heads of executive regional office (Art 58(1) of BGRS constitution). The controlling power of the parliament over the executive is reflected in the provision that the executive council is accountable to the regional legislative council (Art 57(2) of BGRS constitution). In this regard, chief executive (the regional president) is elected by and from among the members of the state council (Art 60(1) of BGRS constitution). The chief executive draws up a list with nominees for the executive council and submits this list for approval of the state council (Art 61(1/f) of BGRS constitution). According to Art 59 of BGRS constitution, the regional executive council have the following major powers and functions such as:-

- To ensure the implementation of laws enacted and decisions passed by the regional state council and federal government and issue regulations and directives

- To draw-up the annual budget, and submit to the regional state council, implement the same upon approval

- To formulate economic and social policies and strategies of the regional state, submit draft laws to the regional state council and implement same upon approval

Chris and Christopher (2014) argued that fair and just consideration and representation of people in executive organs of the government is also one manifestation of any democratic government. As stated elsewhere in this paper, Art 39(3) of FDRE constitution unequivocally recognized "every nation, nationality and people in Ethiopia has the right to a full measure of self-government which includes the right to establish institutions of government in the territory that it inhabits and to equitable representation in state and federal government."

In this regard, it is widely accepted by political analysts and policy-makers that federalism with genuine power sharing is the most viable democratic means of managing conflict in countries with deep divisions, where ethno-nationalist groups are politically mobilized and identity is politically salient. Power sharing is necessary to prevent dominant groups or communities from subjugating others. Hence, as stated elsewhere in this paper the establishment and strengthening of the power-sharing mechanisms in different institutions from the local to the federal level in diversified state seems a precondition to cement unity in diversity and promote democracy at all levels. This principle can be broadened to state that regional institutions should reflect existing diversity on the ground. In spite of this fact, currently the regional executive council is predominantly controlled by indigenous ethnic groups. The regional constitution does not provide for a guaranteed representation of ethnic groups in the regional executive council. The total number of the members of the regional cabinet in BGRS is 17 (empirical data gathered in the council's office by the researcher, 2016, Assosa). Accordingly, all indigenous ethnic groups have representation in regional executive council in BGRS. In this regard, currently the composition of ethnic groups in the regional executive council indicates that 5 members were nominated for the Bertha, 5 members form the Gumuz, 4 members form the Shinasha and 3 members from the Mao and Komo ethnic groups (ibid).

Therefore, at this point it is quite clear that non-indigenous ethnic groups have no representation in regional 
executive council, which means that the regional executive council is entirely controlled by indigenous ethnic groups. But in contrast, as stated above effective representation of various ethnic groups in various regional institutions has a profound effect to enhance sense of regional unity in diversity. Thus, actual ethnic representation and participation in various political institutions will enable all ethnic groups to take charge of their own affairs and accordingly it enhances harmony among the ethnic groups. In multi-ethnic areas as much as possible all ethnic groups should effectively be included in various political institutions at different levels of government, because it has the potential to minimize or eliminate ethnic conflict/tension.

In this context, beside interview information, this study attempted to survey the existing perception of civil servants regarding the representation of ethnic diversities in regional executive council and its effect on regional unity of BGRS. Accordingly, the survey result shows that currently the prevention of the representation of nonindigenous in the regional executive council has been perceived as one major source of regional disunity. For instance, the results in the table 1.4 below show that a significant majority $(85 \%)$ of the respondents argued that prevention of the representation of non-indigenous ethnic groups under the regional executive council in BGRS was perceived as one major source to regional disunity, while very few respondents $(8.5 \%)$ did not agree that this was a source to regional disunity in BGRS.

Table 1.4. The Perception of Civil Servants Regarding the Effect of Absence of Representation of Ethnic Diversities in the Regional Executive Council vis-à-vis Regional Unity in BGRS

$\{$ QUESTION\}: In your perception, absence of the representation of non-indigenous ethnic groups in executive council at the regional level is conceived as a source to regional disunity?

\begin{tabular}{|l|l|l|l|l|l|}
\hline \multirow{5}{*}{ Valid } & Rank Scale & Frequency & Percent & Valid Percent & Cumulative Percent \\
\cline { 2 - 7 } & Strongly agree & 203 & 53.6 & 55.3 & 55.3 \\
\cline { 2 - 6 } & Agree & 119 & 31.4 & 32.4 & 87.7 \\
\cline { 2 - 6 } & Undecided & 13 & 3.4 & 3.5 & 91.3 \\
\cline { 2 - 6 } & Disagree & 26 & 6.9 & 7.1 & 100.0 \\
\cline { 2 - 6 } & Strongly disagree & 6 & 1.6 & 1.6 & \\
\cline { 2 - 6 } & Total & 367 & 96.8 & 100.0 & \\
\hline Missing System & & 12 & 3.2 & & \\
\hline Total & & 379 & 100.0 & & \\
\hline
\end{tabular}

Source: Survey data, 2016-2017

Information gained from interview with higher regional officials reveal that, the main rationale behind the complete exclusion of non-indigenous ethnic group representation in the regional executive council was basically to break the non-indigenous ethnic group monopoly on regional government jobs and the regional economy. As stated above, currently in BGRS non-indigenous ethnic groups are significantly dominating the business sectors in the region (Interview conducted with expert in BGRS trade, industry and transport bureau (2017), Assosa). Apart from this, most of the civil service and judiciary positions were highly dominated by nonindigenous ethnic groups. The participation of indigenous ethnic groups in civil service, judicial positions and business sectors are still minimal in BGRS. In this regard, deliberate deterrence of the representation of nonindigenous in the regional executive council was one basic mechanism to counterbalance the socio-economic dominance of non-indigenous ethnic groups in BGRS. But in contrast, the hitherto evidence indicates that, in BGRS non-indigenous ethnic groups unambiguously claim for representation in the regional executive council.

In addition to this, the legislative council formation mainly as a result of the "first-past-the-post" electoral mode of choosing nominees in ethnically diversified state in its part may further exclude non-indigenous ethnic groups in the executive council by using the system of executive council formation policies possibly aimed at the exclusion of non-indigenous ethnic communities in the region. Because in BGRS there is no clear cut powersharing mechanism among the ethnic groups, nevertheless, all the indigenous groups are represented in the regional executive council. As a result, sometimes some indigenous ethnic group political elites have posed complaints concerning proportional representation within executive council. In fact, this has happened because of the individual's interest to seize power on behalf of their own ethnic groups.

Consociational approaches aim to treat conflicting communities as the basic building blocks of political engagement by institutionalizing them as distinctive or separate entities within the power sharing framework. Federalism with power sharing scheme within the executive institutions at different levels of government is very crucial in BGRS. Because it enables ethnic groups to influence policy-making and enable them to decide issues related to language, education and culture, and the groups are believed to contribute to political stability of the region. In multi-ethnic states, genuine power sharing in different institutions could remain a vital tool to manage ethnic conflicts and accordingly to promote unity.

Indeed, as claimed by various scholars the biggest risk of this model is that the coalition formed after challenging negotiations may easily collapse and thus the polity will have a fragile government. Trust and co- 
operation among the ethnic group actors is a precondition for the successful operation of power sharing model in multi-ethnic states. Furthermore, power sharing assumes that each segment should be loyal to the respective state beyond its ethnic groups. Here, it acknowledges double loyalty (loyalty to the state and to the respective ethnic group). But as argued by Assefa (2012) to be effective power sharing, loyalty to the state must somehow prevail over loyalty to the respective ethnic group. Beside this, he also asserted that it is hardly possible to have effective power sharing unless the political elite shows a clear commitment to it and is willing to 'give and take' (ibid). At least major political elites should basically consider power sharing useful and necessary.

However, in practice these above mentioned preconditions are missing in BGRS as there is strong mistrust among the political elite owing to differing historical narrations and varying conceptions about the future. For instance, different ethnic groups particularly indigenous and non-indigenous ethnic groups in the region are represented by different political parties that indicate the groups are not internally cohesive. Even sometimes in the same political party there exist political disagreements among indigenous ethnic groups.

\subsubsection{Regional Judicial Organ and Ethnic Composition}

In the contemporary Ethiopian federation states enjoy not only legislative and executive functions but also judicial functions. In this regard, Art 67(1) of the BGRS constitution stipulates that "the judicial power of the region is vested in the state supreme court." The regional judicial organ is organized into a three-tier structure that comprises the state Supreme Court, High Court, and First Instance Courts (refer Art 68(1) of BGRS constitution). The president and deputy-president of the regional Supreme Court are appointed by the Regional Council, after being nominated by the regional President (see Art 81(3) FDRE constitution). The other remaining regional judges are also appointed by the regional parliament, upon the recommendation of the State Judicial Administration Council (ibid, Art 81(4 and 5)). However, with regard to the regional Supreme Court and the regional High Courts, the State Judicial Administration Council is obliged, before submitting its recommendation to the regional parliament, to ask for the advisory opinion of the Federal Judicial Administration Council (refer Art 81 (4) of FDRE constitution and Art 69 (3) of BGRS constitution).

In a divided society, fair representation of people in the political system is not limited to legislative and executive organs of the government. But different government institutions which run political and non-political matters shall also reflect the existing ethno-cultural dynamics of that political community to enhance the sense of unity among various communities. This idea has been strongly affirmed by various scholars. In support of this argument for instance, Lijphart (2004: 105) apparently asserted that in divided societies, inclusive representation of all communal groups is essential not only in cabinets and parliaments, but also in the civil service, judiciary, police and military institutions.

Despite the absence of discrimination on basis of recruitment and appointment of judges in BGRS there is also no provision in the constitution of BGRS that contains guaranteed ethnic representation in judicial organ under the region. Constitutionally, any ethnic groups have the opportunity to be appointed as a judge in BGRS. But assume that following violent ethnic conflict, members of one community may not accept a decision from a judge from another community, even if the decision is sound. In this regard, the multi-ethnic composition of the courts can reduce this basic mistrust among the community. Therefore, in multi-ethnic states as much as possible all ethnic groups should effectively be included under judicial institutions at different levels of government, because in its part it has the potential to minimize or eliminate ethnic suspicion.

Interview conducted with state council advisors reveal that both indigenous and non-indigenous ethnic groups are appointed as judges in different levels of court under the region. Since, during a recruitment ethnic background is not taken into account. However, anyone whose educational status, ethical background, competence and age meet the standard set by the judicial organ can be nominated and appointed. In this regard, currently there are total of 135 judges in the region, of this 70 judges were appointed from indigenous ethnic groups while 65 were from non-indigenous ethnic groups (Data gathered from the office of BGRS Supreme Court, 2018, Assosa). Here it is quite clear that, non-indigenous ethnic groups had significant representation under judicial institutions in BGRS. Therefore, based on this empirical information one can claim that the composition of indigenous and non-indigenous ethnic groups are fairly balanced in judicial institutions under BGRS. In fact, the participation of some indigenous ethnic groups in the regional judicial institutions is insignificant relative to their population number. For instance, the appointed judges from the Bertha, Mao and Komo ethnic groups are 15,1 and none respectively in the region.

Beyond interview and pertinent legal document analysis, this study has attempted to survey the existing perception of civil servants concerning the composition of ethnic diversities in judicial institution and its effect on the current regional unity of BGRS. Accordingly, the survey result shows that presently limited participation of some indigenous ethnic groups in judicial institution has been taken as a source to regional disunity of BGRS. For instance, the results in the table 1.5 below show that a significant majority $(78.9 \%)$ of the respondents viewed that limited participation of some indigenous ethnic groups in judicial institutions in BGRS was perceived as a source of regional disunity, while few respondents $(11.4 \%)$ did not agree that this was a source of regional disunity in BGRS. 
Table 1.5. The Perception of Civil Servants Regarding the Composition of Ethnic Diversities in Judiciary vis-àvis Regional Unity in BGRS.

\{QUESTION\}: In your perception, limited participation of some indigenous ethnic groups in judiciary is conceived as a source to regional disunity?

\begin{tabular}{|l|l|r|r|r|r|}
\hline \multirow{5}{*}{ Valid } & Rank Scale & Frequency & Percent & Valid Percent & Cumulative Percent \\
\cline { 2 - 6 } & Strongly agree & 172 & 45.4 & 46.9 & 46.9 \\
\cline { 2 - 6 } & Agree & 127 & 33.5 & 34.6 & 81.5 \\
\cline { 2 - 6 } & Undecided & 25 & 6.6 & 6.8 & 88.3 \\
\cline { 2 - 6 } & Disagree & 40 & 10.6 & 10.9 & 99.2 \\
\cline { 2 - 6 } & Strongly disagree & 3 & .8 & .8 & 100.0 \\
\cline { 2 - 6 } & Total & 367 & 96.8 & 100.0 & \\
\hline Missing System & & 12 & 3.2 & & \\
\hline Total & & 379 & 100.0 & & \\
\hline
\end{tabular}

Source: Survey data, 2016-2017

1.6.4 Constitutional Interpretation Commission

In addition to legislative, executive and judicial institutions, there are also other regional institutions which are very important to promote unity out of diversity in the region. Among these, constitutional interpretation commission (CIC) is one important institution which is designed to promote the shared-rule. According to BGRS constitution, the power to interpret the regional constitution is vested in the hands of regional CIC, which comprises four representatives drawn from each indigenous nationalities of the region (see Art 71 of BGRS constitution). It is also empowered to decide constitutional disputes raised within the region (ibid).

As stated supra effective representation of various ethnic groups in various regional institutions has a profound effect to enhance sense of regional unity in diversity. This means, among other things, in multi-ethnic state recognition of the representation of ethnic diversity has been considered as glue to enhance sense of unity. Thus, actual ethnic representation and participation in various political institutions will enable all ethnic groups to take charge of their own affairs and accordingly it enhances harmony among various ethnic groups. As per the regional constitution, the maximum number of members of CIC is twenty (see Art 71(1) of BGRS constitution). But until now, CIC could not come to effect in BGRS.

In this context, constitutionally it seems like that the establishment of the CIC in BGRS aims to promote the ethnic diversity of the region like a house of federation at the federal level of government. Since, members of CIC are drawn from each indigenous ethnic group of the region. In this regard, BGRS constitution has empowered all indigenous ethnic groups to have four representatives equally irrespective of population size under CIC (ibid). But in contrast, non-indigenous ethnic groups have no representation in CIC. The representation of non-indigenous ethnic groups in CIC are not recognized under BGRS constitution. Which means in BGRS CIC is entirely controlled by indigenous ethnic groups. But as claimed by Lijphart (2004) in divided society fair representation of various ethnic cleavages in different government institutions which run political and non-political matters is very essential in itself to enhance the sense of unity among various societies.

$\mathrm{CIC}$ in BGRS is assisted by the Council of Constitutional Inquiry/CCI (see Art 73 of BGRS constitution and Proclamation No.74/2008 of Benishangul Gumuz region). It has the constitutional power to advise CIC. According to BGRS constitution, CCI comprise eleven members (see Art 72(2) of BGRS constitution). Accordingly, the members of CCI include: President and vice-President of the regional supreme court who also serve respectively as chairman and vice chairman of the CCI, six legal experts appointed by the chief administrator of the region on recommendation by the regional council, who shall have proven professional competence and high moral standing members, and three representatives elected from among members of regional council upon the recommendation of the speaker (ibid). Accordingly, as per Art 73 of BGRS constitution and proclamation number 74/2008 the major powers and duties guaranteed to CCI are:

1) To investigate constitutional disputes according to the constitution. It also investigates constitutional disputes and should the council, upon consideration of the matter, find it necessary to interpret the constitution, it shall submit its recommendations thereon to the Commission

2) Where any regional law is contested as being unconstitutional and such a dispute is submitted to it by any court or interested party, the council shall consider the matter and submit it to the Commission for a final decision

3) When issues of constitutional interpretation arise in the courts, the Council shall:

$>$ Remand the case to the concerned court if it finds that there is no need for constitutional interpretation;

Submit its recommendations to Commission for a final decision if it believes that there is a need for constitutional interpretation 
In BGRS CCI in its composition differs from the CIC because there is no any provision in the constitution of BGRS that contain guaranteed ethnic group representation under CCI. The regional constitution is silent about the ethnic representation in CCI. Hence, constitutionally any ethnic groups of the region have opportunity to be appointed in the CCI. But as interview conducted with advisors of state council speakers reveals that, CCI has not yet been established in BGRS.

\subsection{Ethnic Representation at Woreda Government in BGRS}

The FDRE constitution explicitly prescribes the establishment of lower levels of government in the regional states. But the power to establish lower levels of government has been explicitly provided to the regional states. Beside this, the FDRE constitution has also obliged the regional states to grant adequate power to the lowest units of government. For example, Art 50(4) of the FDRE constitution has clearly stipulated that "state government shall be established at state and other administrative levels that they find necessary. Adequate power shall be granted to the lowest units of government to enable the people to participate directly in the administration of such units."

Arguably, constitutional recognition of local government as the order of government can be linked with the realization of the country's ethnic groups to the right of self-determination, which is a key element of the Ethiopian federal political setup. Because Art 39(3) of FDRE constitution unequivocally recognized "every nation, nationality and people in Ethiopia has the right to a full measure of self-government which includes the right to establish institutions of government in the territory that it inhabits and to equitable representation in state and federal government". For instance, in a similar vein Art 39(2) of BGRS constitution vividly recognized the nation or nationality of the regional state to self-administration within its own defined territory and accordingly to exercise self-rule and fair representation in the political institutions of the region.

Thus, based on the above constitutional provisions, the researcher claims that Woreda administration is one important tiers of the government designed to effect self-administration of ethnic communities at lower tiers of government. In this context, by considering the FDRE constitution, currently all regional states have organized Woredas and Kebeles administrations as legitimate units of local government with legally defined authority and functions. The 2002 revised constitution of BGRS has clearly recognized and organized Woreda administration as one order of government in the region. For instance, according to proclamation No. 86/2002 of BGRS, the region has 20 Woredas. However, the total population size of each Woreda in the region is not uniform, which means it varies from Woreda to Woreda. In addition to this, there are different ethnic groups inhabiting in each Woreda administration of the region. But the nature and magnitude of ethnic diversity is not similar in each Woreda

Constitutionally, the major powers and functions granted to Woreda levels of government under BGRS are: to draw up and determine plans of economic development and social service within its own territorial area and implement policies, laws, regulations and directives issued by the regional state within its own administration (Art 85(1\&2). Furthermore, the regional constitution clearly indicates that each and every Woreda is a body hierarchically subordinate to the regional executive (ibid). The Woreda government in BGRS has been organized with different organs such as, legislative, executive and judicial organs. In BGRS the Woreda government structure replicates regional government and nationality administration structures. For example, alike the regional and nationality administration, each Woreda government in the region adopted a parliamentary form of government.

The BGRS constitution guaranteed the legislative authority of the Woreda administration to a Woreda council, while the administrative power of the Woreda is provided to the Woreda administrative council and its cabinets. The judicial power of the Woreda government is vested in the hands of first instance court. Here, it is possible to claim that Woreda level of government is one basic institutional framework through which ethnic communities of the region can exercise their right of self-administration at the lower level of the government. Institutions of Woreda government are one main avenue through which sense of unity among the ethnic groups can be pursued. The Woreda level institutions should facilitate inclusiveness in terms of the structure to promote unity. Therefore, in the following section the powers and duties of each organ of Woreda administration will be discussed in detail. In addition to this, the ethnic composition of each organ of Woreda administration will be assessed in each selected Woreda of the region.

\subsubsection{Woreda Legislative Council}

In BGRS, Woreda level of government has legislative power. The legislative authority of the Woreda administration is vested in the hands of Woreda council, which is the highest organ in the Woreda administration. It is a body directly elected with plurality electoral system because the members of this council are representatives of the People of the Woreda as a whole and they are elected for a term of five years through direct elections (refer Art 86 (1) and Art 90 (3) of BGRS constitution). It is accountable to the council of nationalities or the state council as the case may be (see Article 87 (1) of BGRS constitution). The major powers and functions of the Woreda council in BGRS as stated in Article 87 of BGRS constitution are: 
1) Approve economic development, social services and administrative plans, programs and budget of the Woreda

2) Follow up the timely undertaking of the basic agricultural development activities in the Woreda, and to ensure that special attention is given to the accomplishment of the task with regard to the development, protection and preservation of natural resources.

3) Without prejudice to the Federal and Regional constitutions and other laws, issue detailed directives to ensure the peace and security of the Woreda

4) Call for questioning the chief administrator including other officials of the Woreda and evaluate the performance of the executive organ.

Thus, the Woreda council is constitutionally empowered to enact Woreda level government laws/directives necessary or incidental to the exercise of Woreda powers and performance of allocated functions. The Woreda council is also constitutionally mandated to exercise oversight over the Woreda executive council. It has powers to approve the budget and expenditure of the Woreda government. It also reviews and approves management and development plans prepared by the Woreda executive council, as well as plans for the management and exploitation of the Woreda's resources. Consequently, to discharge these assigned responsibilities each Woreda council has its own office. Accordingly, by the recommendation of the political party with majority seats in the council, the council elects the speaker and deputy speakers. The speakers are accountable to the respective Woreda council. Deputy speaker acts in the absence of chief speaker. Accordingly, they have responsibility to call and chair the council meetings. Interview conducted with the respondents in the selected Woreda substantiate that both speakers are paid employees in the Woreda council. Conversely, the rest of the Woreda councilors are the unpaid employees of the council (ibid). Perhaps, some members of the council might be permanent employees in one of the sector offices of Woreda administration (ibid).

In accordance with FDRE constitution, every ethnic group has the right to be represented in the federal and regional government (see Art 39(3)). It is also clearly provided in proclamation No. 7 (1992) that an ethnic community has the right to be represented in the Woreda council if it does not have a Woreda of its own. Based on the above provisions, in BGRS some seats were reserved by using a quota system for non-indigenous ethnic groups at the Woreda council to ensure their representation where the electoral process does not guarantee their representation. In fact, the above selected Woredas were basically multi-ethnic Woredas of the region. It means that there is no single ethnic group which constitute a majority in the above selected Woreda administrations. Here territorial autonomy is not the viable option for ethnically diversified Woredas of the region. Thus, in multi-ethnic states the institutional design that typically echo the existing diversities by acknowledging the representation of diverse ethnic groups in different levels of government is considered as one key means to enhance peaceful coexistence among the ethnic cleavages.

Table 1.7. Ethnic Group Composition in the Woreda Council (2015 Woreda Election)

\begin{tabular}{|l|l|l|l|l|}
\hline No & Name of Woreda's & Broad Ethnic Category & Number of Representatives & Total \\
\hline 1 & Bambasi & Indigenous & 63 & 115 \\
\cline { 3 - 5 } & & Non- Indigenous & 52 & 130 \\
\hline 2 & Dangure & Indigenous & 88 & 184 \\
\cline { 3 - 5 } & & Non- Indigenous & 42 & 140 \\
\hline 3 & Assosa & Indigenous & 108 & \\
\cline { 3 - 5 } & & Non- Indigenous & 76 & 139 \\
\hline 5 & Webati & Indigenous & 100 & \\
\hline
\end{tabular}

Source: Data collected by the researcher in selected Woredas of the region

The BGRS constitution does not provide for a guaranteed representation of ethnic groups in the Woreda legislative council. However, in spite of this fact, the practice indicates that non-indigenous ethnic groups have a significant number of representatives in the Woreda legislative council in most of multi-ethnic Woredas. For example, from the above table one can easily understand that in the ethnically diversified Woreda's of the region non-indigenous ethnic groups have a significant representation in the Woreda council. Nevertheless, indigenous ethnic groups had a majority of representation and seats in all of the above selected Woreda councils of the region. Therefore, at this point it is invalid to generalize that non-indigenous ethnic groups are fairly represented in the Woreda council. Since in accordance with their high population number in the above selected Woredas of the region, the representation of non-indigenous ethnic groups in each Woreda council is not this much fair.

Nevertheless, to discharge the entrusted responsibility effectively, each Woreda council has been empowered to organize different standing committees in the respective Woreda council. All standing committees 
are accountable to the corresponding Woreda council and speaker. As per proclamation No. 86/2002 of the region, the total members of each standing committee have to be at least three in number (see Art 29 of the Proclamation No. 86/2002 of BGRS). Thus, data gathered from the Woreda's indicate that, currently all Woreda councils have five standing committees for each sector institutions of Woreda administration. Namely law, governance and justice affairs standing committee, government economy, budget and finance affairs standing committee, capacity building and social affairs standing committee, women's, youth public affairs communication standing committee and economic affairs standing committee. Thus, in accordance with Art 29 of the Proclamation No. 86/2002 of BGRS, the major responsibilities and functions of the standing committees of the Woreda council are:

1) To investigate and supervise the proper implementation of the country, regional and Woreda plan, laws and strategy in the Woreda

2) Follow up and oversight the practical application of the allocated budget in accordance with the plan in Woreda

3) Supervise and secure the applicability of the rights and freedoms of citizens in the Woreda

Based on the following table below, one can easily understand that non-indigenous ethnic groups have significant representation in standing committees of each Woreda council where they are significant in number. Therefore, at this juncture, it is justified to generalize that, non-indigenous ethnic groups were fairly represented in the standing committees of the Woreda council. Indeed, in multi-ethnic state representation of ethnic diversity at different levels of government is essential to achieve unity. Ethnic communities that are excluded at the regional level of government could also be accommodated in local government institutions to address some part of the perception of exclusion that underlies ethnic tension in multi-ethnic areas. In fact, the involvement of various ethnic groups in political processes in multi-ethnic states is basically aimed at enhancing the quality of representative democracy. Therefore, currently in multi-ethnic Woredas of the region, various ethnic communities were significantly represented in Woreda council standing committees.

\subsubsection{Woreda Executive Council}

The executive power of Woreda administration is vested in the hands of Woreda Administrative Council, which is accountable to the Chief Administrator and Woreda Council (see Art 91 (1) of revised BGRS constitution). Each Woreda Administrative Council is comprised of Chief and Deputy Chief Administrator as well as heads of line sector offices which are accountable to the regional administrative council in addition to the Woreda Council (ibid: sub-Art 2). Accordingly, each Woreda Administrative Office comprises nine sector offices namely, Capacity Building and Civil Service Offices, Revenue and Customs Office, Governance, Security and Justice Coordination Office, Militia Office, Economy and Finance Office, Administrative Office, Women's, Youth Public Affairs Communication Office, HIV/AIDS Prevention and Protection Office, and Justice Office; each of these offices are headed by Woreda Cabinet members which are nominated by Woreda Administrator and approved by the Woreda Council. The major powers and functions assigned to the Woreda Administrative council in BGRS as per Art 92 (1) of BGRS constitution are:

1) To implement policies, laws, regulation, directives, plans and programmers issued by the federal government and the regional State;

2) To coordinate the executive organs of the Woreda, follow up and direct their activities;

3) To draw up the Woreda's annual budget, submit it to the Woreda council and implement it upon approval.

4) To draw up socio-economic and administrative plans and submit it to Woreda council for approval and implement same upon approval.

Generally, the executive council in each Woreda administration plays political and administrative role and they have an important role in implementing the decision of the Woreda council in accordance with the laws and regulations of the Woreda. The executive council has also the power to implement policies, laws, regulations, directions, plans and programs issued by the federal government and the regional state. In addition, they coordinate the executive organs of the Woredas, make follow up and direct, collect land use payment, agricultural income tax and other incomes. Based on the law, they prepare fiscal and financial plans and submit it to the Woreda council and implement it on approval. 
Table 1.9. Selected Woreda's Executive Council and Their Ethnic Composition (2015 Regional Election).

\begin{tabular}{|l|l|c|l|c|}
\hline No & Woreda & Total No. of cabinets & Ethnic category & No. of representation \\
\hline 1 & Bambasi & $\mathbf{1 4}$ & Indigenous & $\mathbf{1 3}$ \\
\cline { 3 - 5 } & & & Non- Indigenous & $\mathbf{1 3}$ \\
\hline 3 & Dangure & $\mathbf{1 4}$ & Indigenous & $\mathbf{1}$ \\
\hline 3 & & Non- Indigenous & $\mathbf{1 3}$ \\
\hline 4 & Debati & $\mathbf{1 4}$ & Indigenous & $\mathbf{1 3}$ \\
\hline 5 & Wombera & $\mathbf{1 4}$ & Non- Indigenous & $\mathbf{1}$ \\
\hline & & $\mathbf{1 4}$ & Indigenous & $\mathbf{1 3}$ \\
\hline
\end{tabular}

Source: Data collected by the researcher

The BGRS constitution does not provide for a guaranteed representation of ethnic groups in the Woreda executive council. In fact, in these regions where ethnic diversities are highly salient, the representational rights of ethnic groups should not be limited to the legislative branches of government; the executive and other institutions such as civil service, judiciary, police, and military should also reflect the existing ethnic diversity to indorse the sense of unity among the ethnic segments. Nonetheless, the hitherto practice in the region apparently indicates that in those ethnically diversified Woredas of the region, the representation of non-indigenous ethnic groups in Woreda executive council are insignificant. This is because of the presence of high socio-economic disparity between indigenous and non-indigenous ethnic groups in the region. For instance, illiteracy level is still quite high among indigenous ethnic groups compared with non-indigenous in the region.

Actually, literacy rate is one basic indicator of socioeconomic development among the society. As stated elsewhere in this paper, in BGRS non-indigenous ethnic groups have significantly dominated the business sectors. Beside this, currently most of the civil service positions were highly dominated by non-indigenous ethnic groups. The participation of indigenous ethnic groups in civil service institutions and business sectors is still minimal in BGRS.

Therefore, based on the above stated argument, this study tried to survey the perception of civil servants in the region regarding the economic disparity between indigenous and non-indigenous ethnic groups on interethnic unity under the region. Thus, the survey result shows that currently the prevalence of economic inequality between indigenous and non-indigenous ethnic groups has been considered as one major source of interethnic disunity in the region. For instance, as presented quite clearly in table 1.10 below, a majority (69.7\%) of the respondents perceived that the economic discrepancy between indigenous and non-indigenous ethnic groups under BGRS was perceived as a source of regional disunity, while few respondents $(18 \%)$ did not agree that this was a source of regional disunity in the region.

Table 1.10. The Perception of Civil Servants Regarding the Effect of Economic Discrepancy among Ethnic Groups vis-à-vis Regional Unity under BGRS.

\{QUESTION\}: In your perception, the prevalence of economic discrepancy between indigenous and nonindigenous ethnic groups at Woreda level is conceived as a source to interethnic disunity?

\begin{tabular}{|l|l|r|r|r|r|}
\hline \multirow{5}{*}{ Valid } & Rank Scale & Frequency & Percent & Valid Percent & \multicolumn{1}{l}{$\begin{array}{l}\text { Cumulative } \\
\text { Percent }\end{array}$} \\
\cline { 2 - 6 } & Strongly agree & 194 & 51.2 & 52.9 & 52.9 \\
\cline { 2 - 6 } & Agree & 70 & 18.5 & 19.1 & 71.9 \\
\cline { 2 - 6 } & Undecided & 35 & 9.2 & 9.5 & 81.5 \\
\cline { 2 - 6 } & Disagree & 37 & 9.8 & 10.1 & 91.6 \\
\cline { 2 - 6 } & Strongly disagree & 31 & 8.2 & 8.4 & 100.0 \\
\cline { 2 - 6 } & Total & 367 & 96.8 & 100.0 & \\
\hline Missing System & & 12 & 3.2 & & \\
\hline Total & & 379 & 100.0 & & \\
\hline
\end{tabular}

Source: Survey data, 2016-2017

In the same way, this study tried to survey the perception of civil servants in the region concerning inadequate representation of ethnic diversities in executive council at Woreda levels of government and its effect on interethnic unity in BGRS. Accordingly, the survey result shows that currently the restriction of the representation of non-indigenous in the executive council at Woreda levels of government has been considered 
as a source of interethnic disunity in the region. For instance, the results in the table 1.11 below show that a significant majority $(85 \%)$ of the respondents perceived that absence of proportional representation of nonindigenous ethnic groups under the executive council at Woreda levels of government in the region was perceived as a source to interethnic disunity, while very few respondents $(8.5 \%)$ did not agree that this was a source to regional disunity in the region.

Table 1.11. The Perception of Civil Servants Regarding the Effect of Absence of Proportional Representation of Ethnic Diversities in Executive Council vis-à-vis Regional Unity in BGRS.

\begin{tabular}{|c|c|c|c|c|c|}
\hline \multirow{7}{*}{ Valid } & Rank Scale & Frequency & Percent & $\begin{array}{l}\text { Valid } \\
\text { Percent }\end{array}$ & $\begin{array}{l}\text { Cumulative } \\
\text { Percent }\end{array}$ \\
\hline & Strongly agree & 203 & 53.6 & 55.3 & 55.3 \\
\hline & Agree & 119 & 31.4 & 32.4 & 87.7 \\
\hline & Undecided & 13 & 3.4 & 3.5 & 91.3 \\
\hline & Disagree & 26 & 6.9 & 7.1 & 98.4 \\
\hline & Strongly disagree & 6 & 1.6 & 1.6 & 100.0 \\
\hline & Total & 367 & 96.8 & 100.0 & \\
\hline Missing System & & 12 & 3.2 & & \\
\hline Total & & 379 & 100.0 & & \\
\hline
\end{tabular}

Source: Survey data, 2016-2017

However, the majority of interview respondents similarly explained that, notwithstanding the fact that until now, non-indigenous ethnic groups have a political request for proportional representation in the executive council at Woreda levels of government, the main reason why the regional government deliberately restricted the representation of non-indigenous in the executive council at different levels of government in the region was because it was taken as a special mechanism to counterbalance the socioeconomic domination of nonindigenous ethnic groups in the regional state. Yet, both inadequate representation of non-indigenous ethnic groups in the executive council and the prevalence of socio-economic inequality between indigenous and nonindigenous ethnic groups at Woreda levels of government have on their part significantly affected the political stability of the region.

As stated elsewhere in this paper, actual ethnic representation and participation in local political institutions will enable all ethnic groups to take charge of their own affairs and accordingly it enhances harmony among the ethnic groups. In multi-ethnic areas as much as possible all ethnic groups should be effectively included in various political institutions at different levels of government, which has the potential to minimize or eliminate ethnic conflict/tension. However, the practice on the ground in BGRS shows that in multi-ethnic Woredas of the region, the representation of non-indigenous ethnic groups have been restricted in the Woreda administrative/executive council.

\subsection{Ethnic Representation in Kebele Level of Administration under BGRS}

Similar to other regional states, in BGRS Kebele level of government is the lowest unit of administration following to the Woreda administration. The Kebele level of administration is accountable to the city or Woreda council. According to Art 97 (2) of the 2002 revised BGRS constitution, the Kebele level of administration is structured into Kebele council, Kebele administrative council and social court. The Kebele council is the highest authority under Kebele level of administration. The members of the Kebele council are directly elected by the respective Kebele residents and they are accountable to the people who elected them (Article 98 (1) BGRS revised constitution). The Kebele council is composed of the speaker and deputy speaker of the house; and the number of members of the council is determined by national election law of Ethiopia, the regional constitution and proclamation in accordance with number of each Kebele residents.

As stated above, the other branch of government at the Kebele level of administration is Kebele administrative council, which is the executive organ of government under Kebele administration. Kebele administrative council comprises the administrator and deputy administrator and workers elected from social service-rendering governmental institutions within the Kebele administration. Kebele administrator is appointed by the Kebele council upon the recommendation by political party or parities with majority seat in the council and the deputy administrator and other administrative councils are nominated by the Kebele administrator and approved by the Kebele council.

According to Art 99 of BGRS constitution some major powers and functions guaranteed to Keble Council in the region are:

1) Implement the plans and directives issued from time to time by the Woreda Council and Woreda 
Administrative Council within its Kebele and may issue working directives of the Kebele.

2) Issue directives on social matters and implement it regulation, and directives issued by it superior Administrator organs.

3) Issue detailed guidelines for the implementation of the socio-economic and administrative plans and programmes issued to it by its superior organs and follow up the implementation of these plans and programmes.

4) Ensure the preservation of peace and security as well as the maintenance of law and order.

Empirical evidence gained by the researcher shows that the Kebele institutions do not fully exercising their powers and duties guaranteed by the regional constitution. Like regional and Woreda levels of government, Kebele council in BGRS had standing committees namely; law, governance and justice affairs standing committee, economy, budget and finance affairs standing committees, capacity building and social affairs standing committee, and women's, youth public affairs communication standing committee whose members are 5-7 depending on the necessity of man power needed for that committee. Actually, non-indigenous ethnic groups are significantly represented in both Kebele council and Kebele administrative council under multi-ethnic Woredas of the region. For instance, in Dangure Woreda out of the total 3178 representatives in all Kebele councils of the Woreda, 1218 representatives were from non-indigenous ethnic groups and also in Assosa Woreda out of the total 6681 representatives in each Kebele councils of the Woreda, 3668 representatives were from non-indigenous ethnic groups. The same trend exists in Bambasi, Debati and Wombera Woredas in BGRS.

In fact, under contemporary BGRS if the residents of certain Kebele are dominated by non-indigenous ethnic groups, the majority of representatives under both the Kebele council and Kebele Administrative Council are non-indigenous ethnic groups while, if the residents are dominated by indigenous ethnic groups, the majority of representatives in the Kebele corresponding councils are indigenous ethnic groups. However, if the Kebele residents are mixed (indigenous and non-indigenous ethnic groups), the corresponding representatives in both councils are drown from both indigenous and non-indigenous ethnic groups.

Generally, non-indigenous ethnic groups are in a better manner accommodated at the Kebele level of government than regional and Woreda levels of government under BGRS. Because it is an actual fact that nonindigenous ethnic groups are significantly represented in the Kebele councils and administrative councils in BGRS political dynamics.

\subsection{Conclusion}

In Ethiopia the adoption of a federal political state structure aims at accommodating ethnic diversity and simultaneously nurturing national unity via shared-institutions. Federalism as the institutional arrangement has opted primarily to realize the challenges of ethnic diversity in the country. For example, according to FDRE constitution every nation, nationality and people in Ethiopia has the right to a full measure of self-government which includes the right to establish institutions of government in the territory that it inhabits and to equitable representation in state and federal governments (Art 39(3)). Therefore, all ethnic groups have a full right to be represented in all institutions of regional and the respective local governments. In this regard, regional states are also responsible to recognize and promote the existing diversity based on their own specific local context.

The constitution of BGRS has clearly stated that the regional government shall be organized with four hierarchically structured tiers of government. These are regional government, nationality administration, Woreda and Kebele administrations (Art 45(1) of BGRS constitution). All these tiers of government under the region have been empowered to have their own legislative, executive as well as judicial institutions under their respective jurisdictions. Actually, each tier of government has its own institutions and agencies in which decisions and decision making process are carried out.

The regional state council is representative of the nation, nationalities and people of the regional state as a whole and its members are accountable to the people, constitution and their conscience (see Proclamation No. 31/2002, Article 48 (3) of BGRS). Currently, BGRS council consists of 99 councilors elected directly by the regional people through free, direct and fair elections in secret ballot for a term of five years in each electoral district by using the FPTP electoral system (see Art 48(1\&2) of BGRS constitution). In this context, data gathered by the researcher (2016) reveal that the current practice shows that out of the total 99 seats 40 seats are reserved for Bertha, 35 are reserved for Gumuz, 11 are reserved for Shinasha, 2 are reserved for Mao and 2 for Komo and other 9 seats are reserved for non-indigenous ethnic groups by the 'quota' base. Indeed, the base of this quota system is not the imperative of the regional constitution or other legal document, rather it has been the voluntary decision of ruling regional based political party to accommodate non-indigenous ethnic groups in BGRS.

Based on the above empirical information one cannot argue that non-indigenous ethnic groups are fairly represented in the regional council in accordance with their high population number in the region. Here, it is quite clear that the representation of non-indigenous ethnic groups in BGRS council is not proportional. But in contrast, quite obviously, effective representation of various ethnic groups in various regional institutions has a 
profound effect to enhance sense of regional unity in diversity. However, the restriction of the representation of non-indigenous residents in the regional legislative council in BGRS has been perceived as one major source of regional disunity. In fact, according to higher officials of the region, the main rationale behind the restriction of non-indigenous ethnic group representation in the regional political institutions was basically to break the nonindigenous ethnic group monopoly on regional government jobs and the regional economy. In this regard, the regional government position is that it is one basic mechanism to counterbalance the socio-economic dominance of non-indigenous ethnic groups in BGRS.

As stated above, Chris and Christopher (2014) argued that fair and just consideration and representation of people in executive organs of the government is also one manifestation of any democratic government. However, the prevention of the representation of non-indigenous in the regional executive council in BGRS has been perceived as one major source to regional disunity. In a divided society, fair representation of people in the political system is not limited to legislative and executive organs of the government. But different government institutions which run political and non-political matters shall also reflect the existing ethno-cultural dynamics of that political community to enhance the sense of unity among various communities. In this context, another key issue hindering the effective representation of various ethnic groups in the legislative council at different levels of government in Ethiopia in general and BGRS in particular is the adopted electoral system.

Proclamation No. 7 (1992) clearly recognized that an ethnic community has the right to be represented in the Woreda council if it does not have a Woreda of its own. Based on this provision, in BGRS some seats were reserved for non-indigenous ethnic groups at the Woreda council to ensure their representation where the electoral process does not guarantee their representation. The BGRS constitution does not provide for a guaranteed representation of ethnic groups in the Woreda legislative council. However, in spite of this fact, the practice indicates that non-indigenous ethnic groups have a significant number of representatives in the Woreda legislative council in most of multi-ethnic Woredas. Therefore, at this point it is invalid to generalize that nonindigenous ethnic groups are fairly represented in the Woreda council. Since in accordance with their high population number in the above selected Woredas of the region, the representation of non-indigenous ethnic groups in each Woreda council is not this much fair.

In fact, in these regions in which ethnic diversities are highly salient, the representation of ethnic diversity should not be limited in the legislative branches of government; the executive and other institutions such as the civil service, judiciary, police, and military should also reflect the existing ethnic diversity to indorse the sense of unity among the ethnic segments. Nonetheless, the hitherto practice in the region apparently indicates that under those ethnically diversified Woredas of the region, the representation of non-indigenous ethnic groups in the Woreda executive council are insignificant. However, in contrast, non-indigenous ethnic groups are in a better manner accommodated at Kebele level of government than regional and Woreda levels of government under BGRS. Because evidences indicate that non-indigenous ethnic groups are significantly represented in the Kebele councils and administrative councils in BGRS political dynamics. Data gained by the researcher indicates that the Kebele institutions do not fully exercising their powers and duties guaranteed by the regional constitution.

\subsection{Implications for Policy and Practice}

The findings of the research have implications that both federal policy makers and practitioners in general and policy makers and practitioners of BGRS in particular need to take into account. In this regard, this study offers the following recommendations to policy makers and practitioners for both levels of governments:

1) According to the FDRE constitution every nation, nationality and people in Ethiopia has the right to a full measure of self-government which includes the right to establish institutions of government in the territory that it inhabits and to equitable representation in state and federal governments (Art 39(3)). Therefore, all ethnic groups have a full right to be represented in all institutions of regional and the respective local governments. Therefore, regional states are also responsible to recognize and promote the existing diversity based on their own specific local context. In this regard, now BGRS government should reconsider and decide to increase the number of state council seats essentially to increase the representation of non-indigenous ethnic groups in the regional state council.

2) This study found that non-indigenous ethnic groups are in a better manner accommodated at the Kebele level of government than at Woreda and regional levels of government in BGRS. Non-indigenous ethnic groups are not fairly represented in the regional council in accordance with their high population number in the region. In addition to this, under those of ethnically diversified Woredas of the region the representation of non-indigenous ethnic groups particularly in the Woreda executive council are insignificant. Failure to adequately accommodate or represent non-indigenous ethnic groups in the regional legislative and executive organs of the government in its part is greatly challenging the unity of BGRS. Equitable or proper representation and participation of non-indigenous ethnic groups, particularly, at the regional level political institutions has a positive side and will have a potential in its part to minimize community's dissatisfaction with the political administration. On the other hand, it can 
consolidate and strengthen sense of peaceful coexistence and sub-national unity among various ethnic groups in BGRS. Therefore, BGRS and other regional states of the country should revisit and review its strategy and policies how non-indigenous ethnic groups are represented or accommodated particularly in the executive institutions at Woreda and regional levels of government in the region.

\section{References}

Assefa, F. (2007). Federalism and the Accommodation of Diversity in Ethiopia: A Comparative Study, revised edition. Addis Ababa: Artistic Printing Enterprise.

(2012). Ethiopia's Experiment in Accommodating Diversity: 20 Years' Balance Sheet.

Regional \& Federal Studies, 435-473.

Benedict, K. (1999). The Applicability of the International Legal Concept of Indigenous Peoples in Asia. In J. B. Bell (ed.), the East Asian Challenge for Human Rights Cambridge: Cambridge University Press, pp. 336-77.

(1995). Indigenous Peoples as an International Legal Concept. In B. H. R (ed.), Indigenous Peoples of Asia (pp. 13-34). Ann Arbor: Association of Asian Studies.

Gutmann, A. (1994). Multiculturalism: Examining the Politics of Recognition. 41 William Street- Princeton University.

Jung, C. (2008). The Moral Force of Indigenous Politics Critical Liberalism and the Zapatistas. London: Cambridge University Press.

Kymlicka, W. (2005). Liberal Multiculturalism: Western Models, Global Trends, and Asian Debates. In W. K. He (ed.), Multiculturalism in Asia (pp. 22-55). New York: Oxford.

Kymlicka, W. \& Norman, W. (2000). "Citizenship in Culturally Diverse Societies: Issues, Contexts, Concepts" in Will Kymlicka \& Wayne Norman, eds., Citizenship in Diverse Societies. Oxford: Oxford University Press.

Lijphart, A. (1977). Democracy in Plural Societies. New Haven, CT: Yale University Press.

Majeed, A., Isawa, J. et al (2008). Building on and Accommodating Diversities. In Watts, R., Chattopadhyay, R. Unity in Diversity Learning From Each Other (Volume 1) Building on and Accommodating Diversities (pp. 3-20). New Delhi: Forum of Federations.

Mcewen, N. \& Lecours, A. (2008). Voice or Recognition? Comparing Strategies for Accommodating Territorial Minorities in Multinational States. Journal of Commonwealth and Comparative Politics, Vol. 46: 220-243.

Moreno, L. and Colino, C. in Moreno, L. and Colino, C. (2010) eds: A global dialogue on federalism, diversity and unity in federal countries. vol 7, McGill -Queen's university.

Muluneh, K. (2017). The Paradox of Administration of Nationalities in Post-1991 Ethiopia: The

Case of Benishangul-Gumuz Regional State, International Journal of Advancements in Research \& Technology, Volume 6: 35-65.

Tierney, S. (2004). Constitutional Law and National Pluralism. Oxford \& New York: Oxford University Press.

Vaughan, S. (2003). Ethnicity and Power in Ethiopia (PhD thesis). Edinburgh: The University of Edinburgh.

Yonatan, T. (2008). Institutional Recognition and Accommodation of Ethnic Diversity: Federalism in South Africa and Ethiopia (PhD thesis). University of the Western Cape

\section{Legal Documents}

The Constitution of the Federal Democratic Republic of Ethiopia Proclamation No. 1/1995, Federal Democratic Republic of Ethiopia (Addis Ababa, 1995).

The Constitution of the Benishangul-Gumuz Regional state, Lissane Hig Gazeta of the Benishangul-Gumuz Regional state, 1th Year No 1 Asossa, July 1996

The Revised Constitution of the Benishangul-Gumuz Regional state, Lissane Hig Gazeta of the BenishangulGumuz Regional state, 8th year No. 4, Asossa, 02 December 2002.

The minutes of the Constitutional Assembly held in Assosa 03/12/2002, volume 1

Proclamation number of $73 / 2008$, defining of the internal structure, office structure, Powers and Duties of Council of Nationality Administration in Benishangul Gumuz region.

Proclamation number of 94/2003, Redefining of Powers and Duties of the Executive Organs of the Benishangul Gumuz region.

Proclamation Number of 74/2008, Benishangul Gumuz Region Council of Constitutional Inquiry BenishangulGumuz Regional State Woreda Power Decentralization Administration Established Proclamation No. $8 / 2002$ 